\title{
PENINGKATAN KEMAMPUAN KONSELOR UNTUK MEMFASILITASI PERKEMBANGAN MORAL SISWA SMP DENGAN MENGGUNAKAN MEDIA KOMIK MORAL
}

\author{
Arbin Janu Setiyowati*, Elia Flurentin, Djoko Budi Santosi, Andi Mappiare \\ Jurusan Bimbingan dan Konseling, Fakultas Ilmu Pendidikan, Universitas Negeri Malang, Indonesia \\ Jl. Semarang No. 5 Malang \\ *e-mail: arbin.janu.fip@um.ac.id
}

\begin{abstract}
This community service activity aims to improve the ability of Junior High School Laboratory State University of Malang counselors in facilitating the moral development of junior high school students by using moral comics. The methods for carrying out this service are lectures, guided discussions and guided assignments, workshops and mentoring. The partner in carrying out this dedication activity is the counselor at the Laboratory of SMP State University of Malang. The results obtained are an increase in understanding and ability of teachers to facilitate the moral development of junior high school students appropriately, the indicators are 1) counselors of SMP UM Laboratory have understood the moral development characteristics of SMP students and the importance of moral development of students appropriately 2) counselors of SMP UM Laboratory have understood efforts efforts that can be made to facilitate the moral development of middle school students. 3) counselors of SMP UM Laboratory have been skilled in utilizing moral comics as a medium for moral information services for junior high school students. So that through this moral comic can help overcome the problems of junior counselors in accordance with the characteristics of junior high school students.
\end{abstract}

Keywords: Moral; moral comic media; junior counselor

\begin{abstract}
Abstrak: Kegiatan pengabdian kepada masyarakat ini bertujuan untuk meningkatkan kemampuan konselor SMP Laboratorium Universitas Negeri Malang dalam memfasilitasi perkembangan moral siswa SMP dengan menggunakan komik moral. Metode pelaksanaan kegiatan pengabdian ini adalah ceramah, diskusi terbimbing dan tugas terbimbing, lokakarya dan pembimbingan. Mitra pelaksanaan kegiatan pengabdian ini adalah konselor di SMP Laboratorium Universitas Negeri Malang. Hasil yang diperoleh yaitu adanya peningkatan pemahaman dan kemampuan guru dalam memfasilitasi perkembangan moral siswa SMP secara tepat, indikatornya adalah 1) konselor SMP Laboratorium UM sudah memahami karakteristik perkembangan moral siswa SMP dan pentingnya pengembangan moral siswa secara tepat 2) konselor SMP Laboratorium UM sudah memahami upaya-upaya yang bisa dilakukan untuk memfasilitasi perkembangan moral siswa SMP. 3) konselor SMP Laboratorium UM sudah
\end{abstract}


terampil dalam memanfaatkan komik moral sebagai media layanan informasi moral bagi siswa SMP. Sehingga melalui komik moral ini dapat membantu mengatasi permasalahan konselor SMP yang sesuai dengan karakteristik siswa SMP.

Kata kunci: Moral; media komik moral; konselor SMP

\section{PENDAHULUAN}

Fakta di lapangan memperlihatkan bahwa perilaku peserta didik akhir-akhir ini cenderung menunjukkan degradasi moral yang cukup tinggi. Hal ini dapat dibuktikan dari beberapa hal yaitu tingginya angka penyalahgunaan narkoba di kalangan remaja, seks bebas di kalangan remaja yang angkanya sampai saat ini tercatat 50\% remaja yang melakukan seks bebas, tingginya tingkat kriminalitas yang melibatkan remaja sebagai pelakunya, semakin maraknya tawuran antar pelajar, dan sebagainya. Kondisi ini tentunya sangat memprihatinkan mengingat remaja adalah generasi penerus bangsa yang seharusnya menunjukkan sikap mental yang positif.

Fakta lain yang ditemukan di lapangan adalah degradasi moral akhir-akhir ini justru semakin mengkahawatirkan karena banyak terjadi di tingkat pendidikan menengah yaitu SMP. Banyak siswa SMP yang menunjukkan perilaku menyimpang dari nilai-nilai yang ada. Hasil wawancara dengan konselor di SMP Laboratorium, banyak kasus yang ditangani terkait perkembangan moral siswa SMP. Kasus-kasus terkait moral siswa SMP antara lain, kasus siswa yang berani mengakses konten porno melalui handphone ketika di sekolah, hubungan dengan lawan jenis yang melebihi batas kesusilaan, siswa menunjukkan perilaku yang kurang santun terhadap orang yang lebih tua, siswa mudah mengucapkan kata-kata yang kasar, dan sebagainya. Kasus-kasus yang ditangani konselor tersebut menunjukkan adanya penyimpangan perilaku, khususnya terkait dengan nilai moral di kalangan siswa SMP. Situasi ini mengkhawatirkan mengingat siswa SMP masih masuk tahap remaja awal, fase dimana sedang terjadi proses perkembangan di seluruh aspek kehidupannya. Selain itu Masa remaja merupakan titik penting dalam kehidupan manusia karena banyak kebiasaan-kebiasaan dalam kehidupan sehari-hari yang baik dan buruk dibentuk dan berpengaruh terhadap kehidupan selanjutnya (Santrock, 2012).

Melihat fakta-fakta tersebut di atas, masalah moral adalah tanggung jawab semua pihak. Perlu dilakukan sebuah upaya mendasar untuk menumbuhkan kesadaran pentingnya nilai moral dalam kehidupan kepada remaja khususnya remaja di tingkat SMP. Remaja tingkat SMP perlu mendapat perhatian serius karena untuk mencegah penyimpangan perilaku tersebut semakin menjadi di kehidupan selanjutnya.

Upaya menangkal dan mencegah perilaku-perilaku yang tidak diharapkan seperti disebutkan di atas, adalah dengan mengembangkan potensi peserta didik khususnya pengembangan aspek moral dan memfasilitasi mereka secara sistematik, terprogram dan kolaboratif untuk mampu mencapai standar kompetensi nilai perkembangan/perilaku dan moral yang diharapkan. Upaya ini merupakan wilayah garapan bimbingan dan konseling yang harus dilakukan secara proaktif, intensional dan kolaboratif yang diselenggarakan berbasis data perkembangan peserta didik secara komprehensif dalam berbagai aspek kehidupannya.

Salah satu pelayanan bimbingan dan konseling di sekolah adalah pemberian layanan informasi kepada siswa. Layanan informasi diberikan dengan tujuan untuk memfasilitasi perkembangan peserta didik sehingga fungsi yang diemban adalah fungsi pengembangan dan pencegahan. Pengembangan moral peserta didik dapat di fasilitasi melalui pemberian layanan informasi. Layanan informasi di sekolah diberikan dalam setting klasikal, kelompok dan individu.

Pada kenyataannya, seringkali konselor kesulitan dalam mentransfer pesan yang diberikan kepada siswa melalui layanan bimbingan. Hal tersebut terlihat dari antusiasme siswa yang rendah 
ketika konselor memberikan layanan bimbingan. Konselor dinilai kurang menarik dalam memberikan layanan karena masih menggunakan metode yang konvensional, seperti ekspositori. Siswa merasa jenuh dan menganggap penyampaian layanan informasi dengan ceramah seperti layaknya mereka sedang menerima nasihat, petuah selayaknya yang biasa mereka terima dari orang tua.

Berdasarkan hasil wawancara dengan konselor SMP Laboratorium Universitas Negeri Malang, menunjukkan bahwa sebenarnya sebagian besar konselor (70\%) menyadari bahwa pelayanan BK khususnya yang terkait dengan layanan informasi moral yang mereka rancang belum mampu memfasilitasi perkembangan moral siswa SMP dengan tepat karena hanya menggunakan media yang minim, yang akhirnya berimbas pada ketidaktercapaian tujuan pelayanan BK secara optimal. Konselor juga menyadari bahwa penting untuk memfasilitasi perkembangan moral siswa SMP dengan tepat, namun mereka masih kebingungan mengenai bagaimana langkah konkrit dari upaya tersebut, hanya 30\% saja yang sudah mulai mencoba memfasilitasi perkembangan moral siswa dengan langkah-langkah yang bervariasi. Sebagian besar konselor (70\%) menganggap upaya memfasilitasi perkembangan moral siswa SMP melalui pemanfaatan media pelayanan yang bervariatif merupakan hal yang rumit dan sulit dilakukan.

Dari hasil studi pendahuluan dapat disimpulkan bahwa selama ini konselor di SMP Laboratorium UM menghadapi kendala dalam upaya memfasilitasi perkembangan moral siswa SMP. Kendala yang dihadapi yaitu dalam pemilihan strategi layanan dan pemilihan media yang tepat untuk memfasilitasi perkembangan moral siswa SMP. Kendala yang dihadapi ini mengakibatkan upaya untuk memfasilitasi perkembangan moral siswa kurang berjalan optimal sehingga tidak banyak membawa perubahan perilaku pada siswa.

Membicarakan moral bagi remaja seakan ditangkap kesan bahwa moral adalah suatu bahasan yang cukup berat dan menyangkut urusan dengan Tuhan. Remaja cenderung resisten ketika lingkungan terutama orang dewasa memberikan nasihat ataupun masukan tentang moral. Mereka cenderung mengabaikan dan menganggap semua masukan dari lingkungan sebagai hal yang tidak penting. Menyikapi kondisi tersebut penting kreatifitas dalam penyampaian informasi tentang moral kepada remaja. Informasi moral haruslah dikemas seringan mungkin, tanpa kesan menggurui dan dekat dengan kehidupan remaja. Untuk itu diperlukan kehadiran sebuah media yang dianggap efektif menjawab permasalahan tersebut terutama penyampaian informasi moral oleh konselor di sekolah.

Melalui media, konselor dan siswa berusaha untuk melakukan sebuah komunikasi. Komunikasi tersebut berupa penyampaian pesan dari konselor yang kemudian diterima oleh siswa berupa pemaknaan dan pemahaman dari sebuah pesan tersebut. Pesan yang diberikan oleh konselor berupa simbol-simbol verbal maupun non verbal. Ketepatan penyampaian simbol-simbol dalam komunikasi tergantung pada seberapa jauh ketepatan penerima dalam menafsirkan informasi yang diberikan pengirim pesan.

Gagne (dalam Sadiman, dkk, 2002) menyatakan bahwa media adalah berbagai jenis komponen dalam lingkungan siswa yang dapat merangsangnya untuk belajar. Kemudian Briggs (dalam Sadiman, dkk, 2002) menyatakan bahwa media adalah segala alat fisik yang dapat menyajikan peran serta merangsang siswa untuk belajar. Dari pernyataan tersebut dapat disimpulkan bahwa media dapat menyalurkan sebuah pesan kepada seseorang yang membutuhkan pesan tersebut, dalam hal ini siswa. Media yang menarik akan menumbuhkan minat dan motivasi bagi siswa untuk belajar mengenai hal-hal penting dalam mencapai perkembangannya.

Berdasarkan hasil penelitian Setiyowati dan Simon (2015), salah satu media yang dapat digunakan konselor dalam memberikan layanan informasi mengenai moral adalah komik. komik 
merupakan bacaan yang dekat dengan kehidupan remaja khususnya siswa SMP. Hal ini selaras dengan yang disampaikan Atmowiloto (1982) yang mengatakan komik adalah suatu bentuk sajian cerita dengan seri gambar yang lucu. Buku komik menyediakan ceritera-ceritera yang sederhana, mudah ditangkap, dan dipahami isinya, sehingga sangat digemari oleh anak-anak maupun orang dewasa. Melalui komik diharapkan pesan moral dapat tersampaikan dengan baik dan mampu menginspirasi siswa SMP untuk menunjukkan perilaku yang positif. Komik moral yang dihasilkan dan dibutuhkan oleh siswa SMP terdiri dari empat tema, yaitu tema keluarga, hubungan dengan lawan jenis, persahabatan dan teknologi. Komik moral yang digunakan sebagai media informasi dibuat dengan berbagai gambar dan cerita yang sederhana dan disesuaikan dengan karakteristik siswa SMP, serta menggunakan bahasa yang mudah dipahami siswa agar mereka tertarik dan berkenan untuk membacanya.

Berdasarkan hasil analisis situasi tersebut, maka diajukan kegiatan pengabdian bagi masyarakat untuk meningkatkan kemampuan konselor dalam memfasilitasi perkembangan moral siswa SMP melalui pemanfaatan media komik moral. Melalui kegiatan pengabdian ini diharapkan dapat meningkatkan kemampuan professional konselor khususnya di SMP Laboratorium Universitas Negeri Malang dalam memanfaatkan komik moral untuk memfasilitasi perkembangan moral siswa SMP.

\section{METODE}

Upaya untuk mentransfer dan merealisasi pemanfaatan komik moral dalam rangka memfasilitasi perkembangan moral siswa SMP, maka tim pengabdian menggunakan beberapa metode, yaitu: 1) Ceramah bervariasi, yaitu metode yang digunakan untuk menyampaikan materi pentingnya meningkatkan kualitas pelayanan BK khususnya layanan informasi moral bagi siswa SMP dengan memanfaatkan komik moral. 2) Diskusi dan Tugas Terbimbing, yaitu metode yang digunakan untuk mendalami materi tentang penerapan komik moral untuk memfasilitasi perkembangan moral siswa SMP. 3) Lokakarya, yaitu metode yang digunakan untuk melatih konselor dalam menerapkan pemanfaatan komik moral dalam pemberian layanan informasi moral bagi siswa SMP, melalui bimbingan fasilitator. 4) Pendampingan, yaitu metode yang digunakan untuk menjembatani konselor dalam memberikan layanan informasi bagi siswa SMP melalui realisasi pemanfaatan komik moral, dengan bimbingan dan bantuan konsultasi dari fasilitator.

\section{HASIL DAN PEMBAHASAN}

Pelaksanaan kegiatan pengabdian kepada masyarakat ini dilakukan dalam empat tahapan yaitu 1) Lokakarya penerapan komik moral untuk memfasilitasi perkembangan moral siswa SMP, 2) modelling penerapan komik moral sebagai media layanan informasi moral untuk siswa SMP, 3) pendampingan penerapan komik moral sebagai media layanan informasi moral untuk siswa SMP, 4) konsultasi terbimbing hasil penerapan komik moral untuk memfasilitasi perkembangan moral siswa SMP. Paparan dari 4 tahapan kegiatan pengabdian adalah sebagai berikut.

\section{Lokakarya Penerapan Komik Moral untuk Memfasilitasi Perkembangan Moral Siswa SMP}

Kegiatan pertama dalam pengabdian kepada masyarakat ini adalah kegiatan peningkatan kemampuan konselor SMP Laboratorium UM dalam memfasilitasi perkembangan moral siswa SMP dengan menggunakan komik moral. Kegiatan peningkatan kemampuan konselor ini dilakukan dalam bentuk lokakarya. Kegiatan lokakarya dilaksanakan di gedung kuliah bersama (GKB) FIP UM pada tanggal 3 Oktober 2018. 
Materi lokakarya disampaikan oleh tim pelaksana pengabdian yang bertindak sebagai fasilitator. Materi lokakarya dibagi dalam tiga sesi. Secara garis besar pelaksanaan penyampaian materi dipaparkan pada tabel 1 .

Tabel 1. Pelaksanaan Lokakarya Peningkatan Kemampuan Konselor dalam Memfasilitasi Perkembangan Moral Siswa SMP dengan Menggunakan Komik Moral

\begin{tabular}{lll}
\hline No & \multicolumn{1}{c}{ Materi } & \multicolumn{1}{c}{ Fasilitator } \\
\hline 1 & Karakteristik Perkembangan Moral Siswa SMP & Prof. Dr. Andi Mappiare, M.Pd. \\
2 & Biblioedukasi dalam Layanan BK & $\begin{array}{l}\text { Dra. Elia Flurentin, M.Pd. dan Drs. Djoko } \\
\text { Budi Santoso,M.Pd. }\end{array}$ \\
3 & $\begin{array}{l}\text { Pemanfaatan Komik Moral dalam Memfasilitasi } \\
\text { Perkembangan Moral Siswa SMP }\end{array}$ & Dr. Arbin Janu Setiyowati, M.Pd. \\
\hline
\end{tabular}

Kegiatan lokakarya dibuka oleh ketua tim pelaksana pengabdian. Sesuai dengan rancangan yang ditetapkan, kegiatan penyampaian materi pertama dilakukan oleh anggota tim pelaksana pengabdian yaitu Prof. Dr. Andi Mappiare, M.Pd. Materi yang disampaikan adalah perkembangan moral siswa SMP. Metode yang digunakan adalah ceramah, yang disusul dengan kegiatan tanya jawab dan pemberian tugas penyusunan asesmen perkembangan moral siswa SMP.

Kegiatan penyampaian materi kedua dilakukan oleh anggota pelaksana pengabdian yaitu Dra. Elia Flurentin, M.Pd., dan Drs. Djoko Budi Santoso, M.Pd., yang menyampaikan materi mengenai biblioedukasi dalam pelayanan BK. Metode yang digunakan adalah ceramah dan tanya jawab.

Kegiatan penyampaian materi ketiga, dilaksanakan oleh ketua pelaksana kegiatan pengabian yaitu Dr. Arbin Janu Setiyowati, M.Pd yang menyampaikan materi mengenai pemanfaatan komik moral dalam memfasilitasi perkembangan moral siswa SMP. Metode yang digunakan adalah metode ceramah, tanya jawab dan sharing pengalaman dalam memfasilitasi perkembangan moral siswa.

Setelah kegiatan penyampaian materi selesai dilaksanakan, langkah berikutnya adalah diskusi bersama antar peserta lokakarya. Kegiatan diskusi diarahkan untuk menyamakan persepsi konselor mengenai pentingnya memfasilitasi perkembangan moral siswa secara tepat. Diharapkan dengan penyamaan persepsi ini, semua konselor menaruh perhatian terhadap perilaku yang dimunculkan siswa baik perilaku positif maupun negatif dan dapat bekerja sama dalam memfasilitasi perkembangan moral siswa secara tepat.

Pada akhir kegiatan dilakukan kegiatan pemberian tugas yaitu berlatih merancang bentuk asesmen perkembangan moral siswa SMP. Asesmen yang dikembangkan dalam latihan untuk setiap konselor berbeda-beda disesuaikan karakteristik dan kebutuhan siswa dari masing-masing konselor. Kegiatan penugasan diakhiri dengan memberi kesempatan konselor untuk melaporkan hasil rancangannya.

Sesuai dengan rencana, untuk melihat respon peserta terhadap kegiatan pelatihan, selama proses lokakarya dilakukan evaluasi. Evaluasi proses dilakukan melalui pengamatan. Berdasarkan hasil evaluasi proses, dapat digarisbawahi bahwa lebih dari $80 \%$ peserta lokakarya aktif dan penuh perhatian dalam mengikuti kegiatan lokakarya. Dengan demikian dapat disimpulkan bahwa kegiatan lokakarya dapat berjalan dengan baik.

Pada akhir kegiatan dilakukan evaluasi output terhadap peserta lokakarya. Berdasarkan hasil evaluasi output, dapat diketahui bahwa rata-rata kemampuan guru dalam merancang bentuk penanganan perilaku siswa secaratepat sangat bagus, yaitu lebih dari $80 \%$ guru memahami bagaimana merancang penanganan perilaku siswa secara tepat. Secara garis besar hasil evaluasi proses dan hasil (output), disajikan pada tabel 2. 
Tabel 2. Hasil Evaluasi Kegiatan Pelatihan

\begin{tabular}{llc}
\hline No & \multicolumn{1}{c}{ Aspek } & Keberhasilan \\
\hline 1 & Pemahaman tentang karakteristik perkembangan moral siswa SMP & $100 \%$ \\
2 & Pemahaman tentang biblioedukasi dalam penyelenggaraan layanan BK & $80 \%$ \\
3 & Pemahaman tentang penerapan komik moral dalam memfasilitasi & $80 \%$ \\
& perkembangan moral siswa SMP & \\
4 & Pemahaman tentang rancangan asesmen perkembangan moral siswa SMP & $80 \%$ \\
5 & Kepuasan terhadap kegiatan lokakarya & $100 \%$ \\
\hline
\end{tabular}

Modelling Penerapan Komik Moral untuk Memfasilitasi Perkembangan Moral Siswa SMP

Tahap kedua dari pelaksanaan kegiatan pengabdian masyarakat adalah pemberian contoh penerapan komik moral untuk memfasilitasi perkembangan moral siswa SMP. Tujuan pemberian contoh ini adalah untuk memberikan gambaran kepada konselor mengenai penerapan komik moral sebagai media layanan informasi moral siswa SMP. Diharapkan dengan pemberian contoh ini konselor sekolah benar-benar dapat memanfaatkan komik moral seoptimal mungkin.

Pemberian contoh penerapan komik moral dilakukan pada tanggal 9 Oktober 2018. Tim pengabdian dibantu oleh mahasiswa yang dilibatkan dalam kegiatan pengabdian, menyajikan informasi moral kepada siswa menggunakan komik moral. Tim pengabdian diberikan kesempatan oleh sekolah untuk memberikan layanan klasikal di kelas tujuh ICP. Pelaksanaan contoh penerapan komik moral ini berlangsung selama 1 jam pelayanan (40 menit).

Mahasiswa yang sudah ditunjuk berperan sebagai konselor model yang akan memandu layanan klasikal menyajikan layanan informasi moral kepada siswa melalui komik moral. Di kegiatan awal, konselor model mengajak siswa tanya jawab mengenai kegemaran mereka membaca komik. Siswa dengan antusiasnya menceritakan kegemarannya membaca komik. Setelah tanya jawab berakhir, konselor model mengenalkan media komik moral yang akan digunakan dalam kegiatan tersebut. Setelah pengenalan media komik moral, konselor model meminta siswa membuat kelompok kecil berisi 2-3 orang. Masing-masing kelompok diberi satu judul komik moral yang berbeda-beda (Gambar 1).

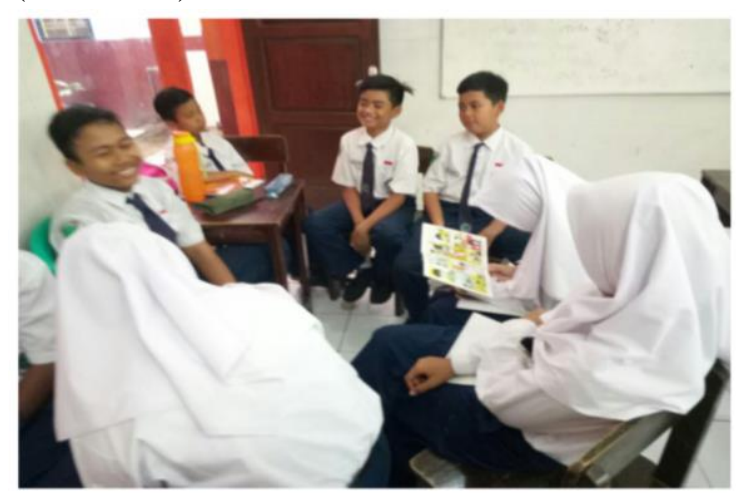

\section{Gambar 1. Suasana Kegiatan Modelling Penerapan Komik Moral}

Pada kegiatan inti, siswa dalam kelompok terkondisikan untuk membaca komik moral. Setelah kegiatan membaca komik moral selesai, konselor model meminta siswa untuk menceritakan kembali isi komik dengan bahasanya sendiri. Setelah itu konselor model memandu kegiatan diskusi dengan mengajukan beberapa pertanyaan refleksi terkait isi komik moral. Dari hasil pengamatan, seluruh siswa yang ditunjuk untuk mengemukakan pendapatnya, semuanya mampu mengungkapkan pendapatnya sesuai yang diharapkan.

Pada kegiatan penutup, konselor model mengajak siswa untuk membuat kesimpulan dari kegiatan pelayanan hari ini. Dari kesimpulan yang dibuat mengenai pentingnya menunjukkan 
perilaku dan sikap yang positif dalam kehidupan sehari-hari, konselor model memberikan motivasi kepada seluruh siswa untuk selalu bersikap dan berperilaku positif. Setelah itu konselor model mengakhiri layanan klasikal dengan memberikan pesan kepada siswa untuk mengimplementasikan pesan komik moral dalam interaksi sosialnya di kehidupan sehari-hari.

\section{Pendampingan Penerapan Komik Moral Sebagai Media Layanan Informasi Moral untuk Siswa SMP}

Kegiatan pendampingan penerapan komik moral sebagai media layanan informasi moral dalam layanan klasikal di kelas dilakukan pada tanggal 15-17 Oktober 2018. Pada kegiatan pendampingan penerapan komik moral ini, tim pelaksana dibantu oleh mahasiswa yang sudah ditunjuk sebelumnya. Bentuk kegiatan pendampingan ini adalah tim pengabdian melakukan observasi langsung ke kelas. Kegiatan observasi dilakukan untuk melihat bagaimana penerapan komik moral oleh konselor. Semua tingkatan kelas mulai dari kelas tujuh sampai dengan kelas Sembilan di SMP Laboratorium UM menjadi sasaran kegiatan observasi. Total kelas yang diobservasi ada 3 kelas dan masing-masing kelas diobservasi pada hari yang berbeda. Tim pengabdian mengikuti keseluruhan rangkaian kegiatan klasikal dari awal sampai akhir (Gambar 3).

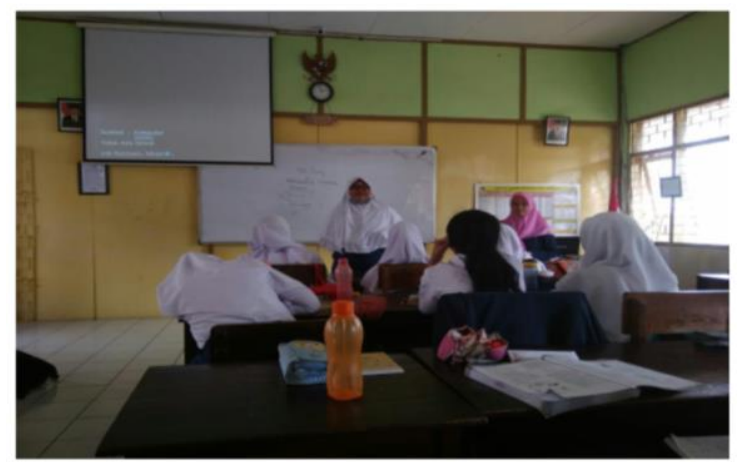

\section{Gambar 2. Suasana Kegiatan Penerapan Komik Moral Oleh Konselor SMP Lab. UM}

Berdasarkan hasil pendampingan yang dilakukan oleh tim pelaksana pengabdian yang dibantu oleh mahasiswa, layanan klasikal di seluruh kelas berjalan kondusif, dan semua siswa nampak aktif mengikuti pelaksanaan kegiatan. Kegiatan pendampingan yang dilakukan yaitu tim pengabdian masuk ke kelas mengikuti proses pelayanan yang dilaksanakan oleh konselor. Selama proses pelayanan, tim pengabdian mengamati interaksi konselor dengan siswa selama proses pelayanan. Dari hasil pengamatan, tampak bahwa suasana kelas lebih kondusif dibandingkan ketika konselor menyampaikan informasi moral tanpa menggunakan komik moral. Hal ini dapat terlihat dari meningkatnya partisipasi siswa selama proses pelayanan. Bahkan ada beberapa siswa yang belum mendapatkan kesempatan mengemukakan pendapatnya karena keterbatasan waktu. Hasil yang tampak adalah siswa mereaksi positif pendekatan konselor dalam memberikan layanan informasi moral menggunakan komik moral.

Berdasarkan hasil evaluasi outcome, dapat disimpulkan bahwa seluruh konselor SMP Laboratorium dapat menerapkan komik moral sebagai media layanan informasi moral bagi siswa secara tepat, meskipun masih dijumpai beberapa kendala dalam penerapannya. Dari hasil pendampingan yang dilakukan oleh tim pengabdian, dapat disimpulkan bahwa konselor SMP Laboratorium UM mengalami peningkatan kemampuan dalam memfasilitasi perkembangan moral siswa secara tepat. Dari total 3 konselor yang mendapat pelatihan peningkatan kemampuan konselor dalam memfasilitasi perkembangan moral siswa menggunakan media komik moral, $100 \%$ konselor dapat menerapkan komik moral secara tepat. 
Kegiatan pendampingan penerapan komik moral yang dilakukan oleh tim pengabdian di semua tingkatan kelas di SMP Laboratorium UM berjalan cukup lancar. Semua anggota tim pengabdian dapat menyelesaikan tugasnya untuk mendampingi keseluruhan proses layanan klasikal di kelas dengan baik. Hal ini juga didukung adanya kerjasama yang baik dari pihak sekolah terutama konselor. Kendala yang dihadapi oleh tim pengabdian dalam kegiatan monitoring ini adalah kesulitan menyesuaikan waktu untuk pendampingan kegiatan layanan klasikal di kelas. Hal ini dikarenakan bersamaan dengan agenda kegiatan di kampus yang pelaksanaannya hampir bersamaan dengan kegiatan pendampingan.

\section{Konsultasi Hasil Penerapan Komik Moral Untuk Memfasilitasi Perkembangan Moral Siswa SMP}

Pada tahapan ini, kegiatan yang akan dilakukan adalah konsultasi konselor kepada tim pelaksana pengabdian mengenai hasil penerapan komik moral untuk memfasilitasi perkembangan moral siswa SMP. Di dalam kegiatan konsultasi, konselor diminta untuk mengungkapkan bagimana proses pemanfaatan komik moral dalam upaya memfasilitasi perkembangan moral siswa SMP dan kendala yang dihadapi dalam penerapan komik moral. Setelah itu, konselor bersamasama tim pelaksana pengabdian membahas proses kegiatan pemanfaatan komik moral dan kendala yang dihadapi oleh konselor serta bagaimana upaya pemecahannya. Proses kegiatan konsultasi ini dilakukan secara Focus Group Discussion (FGD).

Kegiatan konsultasi hasil penerapan komik moral untuk memfasilitasi perkembangan moral siswa SMP dilaksanakan pada tanggal 30 Oktober 2018 (Gambar 3). Pada tahap ini masingmasing konselor menceritakan pengalamannya dalam menerapkan komik moral sebagai upaya memfasilitasi perkembangan moral siswa SMP. Seluruh konselor SMP laboratorium UM menerapkan komik moral melalui kegiatan layanan klasikal. Layanan klasikal di SMP berlangsung dalam waktu 1 x 40 menit.

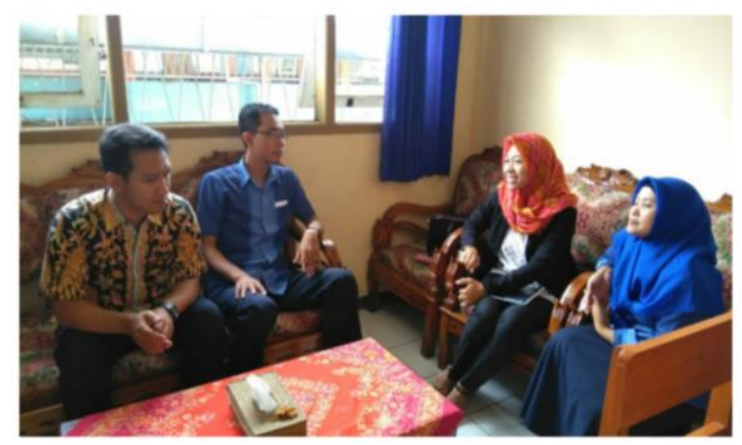

Gambar 3. Suasana Kegiatan Penerapan Komik Moral Oleh Konselor SMP Lab. UM

Skenario yang dijalankan oleh masing-masing konselor berbeda dalam penerapan komik moral. Konselor di kelas VII menyajikan komik moral dengan cara membagi siswa ke dalam 8 kelompok. Masing-masing kelompok membaca komik moral dengan judul yang berbeda. Setelah membaca komik moral, setiap kelompok mengirimkan perwakilan dari kelompokya untuk menceritakan kembali isi komik moral yang telah dibaca kepada kelompok lain. Setelah semua kelompok mengerti isi dari komik moral, konselor memandu siswa untuk merefleksikan pesan moral dari masing-masing komik yang dikaitkan dengan kehidupa sehari-hari siswa.

Konselor di kelas VIII menyajikan komik moral sebagai media layanan informasi moral siswa SMP dengan cara men-scan komik moral dan disajikan dalam bentuk tayangan menggunakan LCD. Strategi ini dilakukan oleh konselor mengingat antusiasme yang tinggi dari siswa untuk ikut serta dalam kegiatan pemanfaatan komik moral namun jumlah komik moral yang 
tersedia terbatas. Setelah semua siswa selesai membaca, konselor memimpin jalannya diskusi dengan memberikan kesempatan siswa menceritakan kembali isi komik moral dan pesan moral apa yang diperoleh dari komik tersebut. Selain itu konselor juga meminta siswa menceritakan pengalaman yang serupa dengan isi komik moral tersebut.

Konselor di kelas IX menyajikan komik moral dengan cara memberi kesempatan seluruh siswa untuk membaca komik moral secara bergantian kemudian meminta perwakilan siswa menceritakan kembali isi komik moral di depan kelas. Setelah itu konselor memberi kesempatan kepada seluruh siswa untuk memberikan balikan terkait pesan moral dari setiap komik moral dan meminta siswa menceritakan pengalamannya yang sesuai dengan isi komik moral. Kegiatan diakhiri dengan konselor memberikan penguatan kepada siswa mengenai pesan moral yang dapat dipelajari dari komik moral tersebut.

Setelah melaporkan proses penerapan komik moral, seluruh konselor menceritakan kendala yang ditemui dalam upaya penerapan komik moral dalam memfasilitasi perkembangan moral siswa. Beberapa kendala yang disampaikan oleh konselor antara lain: 1) kurang tepatnya pengelolaan waktu sehingga alokasi waktu yang tersedia tidak mencukupi, dan 2) di awal kegiatan kelas cenderung gaduh karena antusias siswa yang tinggi untuk membaca komik moral.

Setelah semua konselor menceritakan pengalamannya dalam menerapkan komik moral dalam pelayanan klasikal di kelas dan kendala-kendala yang ditemui di lapangan, tim pelaksana pengabdian mengajak konselor mendiskusikan hasil penerapan komik moral dalam pelayanan klasikal di kelas. Diskusi yang difasilitasi oleh tim pelaksana pengabdian yaitu bagaimana respon siswa terkait pemanfaatan komik moral dan identifikasi solusi yang bisa dilakukan konselor untuk mengatasi kendala yang dihadapi.

Secara umum pelaksanaan tahapan kegiatan ini berjalan lancar dan sesuai dengan yang diharapkan. Semua konselor antusias menceritakan pengalamannya dan aktif memberi balikan dan solusi atas permasalahan yang dihadapinya.

\section{SIMPULAN}

Kesimpulan dari pelaksanaan kegiatan pengabdian kepada masyarakat di SMP Laboratorium UM dalam rangka peningkatan kemampuan konselor dalam memfasilitasi perkembangan moral siswa menggunakan komik moral antara lain: 1) Konselor SMP Laboratorium UM sudah memahami karakteristik perkembangan moral siswa SMP dan pentingnya pengembangan moral siswa secara tepat. 2) Konselor SMP Laboratorium UM sudah memahami upaya-upaya yang bisa dilakukan untuk memfasilitasi perkembangan moral siswa SMP. 3) Konselor SMP Laboratorium UM sudah terampil dalam memanfaatkan komik moral sebagai media layanan informasi moral bagi siswa SMP.

Saran yang diajukan dari hasil pelaksanaan kegiatan pengabdian kepada masyarakat di SMP Laboratorium UM dalam rangka peningkatan kemampuan konselor dalam memfasilitasi perkembangan moral siswa menggunakan komik moral antara lain: 1) Perguruan Tinggi khususnya Universitas Negeri Malang hendaknya meningkatkan instensitas kegiatan pengabdian kepada masyarakat terutama dalam bidang pendidikan sehingga keberadaan perguruan tinggi benar-benar dirasakan manfaatnya oleh masyarakat. 2) Sekolah, hendaknya menyediakan lingkungan yang kondusif untuk pengembangan moral siswa dengan pemberian teladan perilaku dari seluruh personil sekolah. 3) Konselor sebagai tenaga pendidik profesional hendaknya senantiasa meningkatkan kemampuan profesionalnya khususnya dalam upaya memfasilitasi perkembangan moral siswa SMP. 


\section{DAFTAR RUJUKAN}

Atmowiloto, A. (1982). Komik dan Kebudayaan Nasional. Majalah Analisis Kebudayaan, Tahun ke II, Nomor 1. Jakarta: Departemen Pendidikan dan Kebudayaan

Sadiman, A.S., dkk. (2002). Media Pendidikan: Pengertian, Pengembangan, dan Pemanfaatannya. Jakarta: Raja Grafindo Persada.

Setiyowati, A.J., \& Simon, I.M. (2015). Pengembangan Komik Moral Untuk Memfasilitasi Perkembangan Moral Siswa SMP. Laporan Penelitian DRPM. Tidak Diterbitkan. Malang: Universitas Negeri Malang.

Santrock, J.W. (2012). Life-Span development. Perkembangan Masa Hidup. Alih Bahasa Oleh Juda Damanik, Achmad Chusairi. Jakarta: Erlangga 